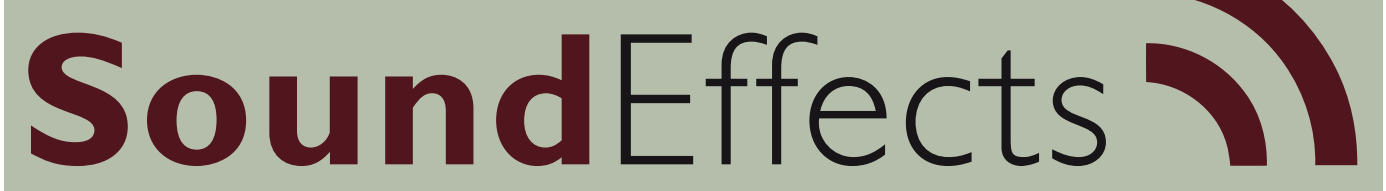

An Interdisciplinary Journal of Sound and Sound Experience

\title{
Norie Neumark
}

\section{Voicing memories}


Last night as I was falling asleep, I put in my earbuds to listen to an audiobook. To get into the Nordic mood to write for a journal coming out of Scandinavia, I scrolled to one of Henning Mankell's famous detectives, Kurt Wallander. On the verge of sleep, somewhere between consciousness and unconsciousness - like memory itself - I listened to Wallander, through his narrator, listening to the room at the scene of the crime, waiting for it to speak to him, to voice what had happened there. Through the haze of half-sleep I wondered whose memory was being voiced in that assemblage comprised of the iPod and earbuds, the audiobook, the room, the narrator, the author and my own memories of watching Krister Henriksson play Wallander and of listening to other Wallander books? And when I woke today and slid the earbuds out of my ears, I felt ready to attend to assemblages and the memories that they voice.

New materialism has attuned us to listen to 'other' voices - from animals to things, from technologies to places, from individual relationships to assemblages. In this essay I will focus on how memory is at play when human voices converse with these other voices. To explore voicings of memory I will listen to examples of contemporary art: from archives to remixes, from performances to places. Through the work of thinkers such as Donna Haraway, Don Ihde, Salomé Voegelin and Erin Manning I understand that listeners, including myself, always/already bring their own memories to such listening. As a complicit, 'situated' listener I will attend to the examples through a mode of 'intersubjective' and co-compositional listening (Haraway, 1988; Voegelin, 2010, 2015; Manning, 2016; Ihde, 2007). Such an approach does not, I contend, sidestep theoretical analysis, but rather grounds and deepens it in ways that will contribute to both voice studies and memory studies. Before turning to the examples, I need to briefly introduce my understanding of voice and the other concepts that animate this article: new materialism, assemblage and memory.

\section{Voice, new materialism, assemblage ...}

Human voice has been widely theorised, from the metaphorical political to the literal sonic and much in between and across. Various approaches to thinking voice attune us to the ways in which it calls to us across spaces, time and media - speaking of intimate connections - talking, singing, whispering, breathing - between us and others (human and non-human). ${ }^{1}$ Voice, as both noun and verb at once, provokes us to listen to its performativity too. Voices are performatively imbricated in 'a way of speaking [... that] produces bodies rather than representing them', as Laura Cull puts it (2012, p. 83). In its complexity human voice is always both located and intersubjective, from its very first breath that vibrates within and leaves a body. This breath, and with it the spoken voice it animates, connects us to the place through which it reverberates and the others in that place and in the shared medium of air. Voice 
affectively and performatively connects speaking and listening bodies - human and more-than-human - with each other as well as through the spaces and places they share. This connection to place and atmosphere resonates with the way postphenomenologist Don Ihde, for instance, attuned us perceptually to the 'voice of the environment, of the surrounding life-world' (Ihde, 2007, pp. 23).

Early on, Ihde attended to the voices of material things and the material voices of things, listening, he said, to the way 'the voice of each thing bespeaks something of its per-sona' (Ihde, 2007, pp. 23, 115-116, 154). Per-sona, persona - already the human and other entangle and blur through this manifestation of voice and sound. To expand our listening to these voices of the material things of the world, Ihde argued, we need to widen our thinking and move beyond an understanding of speaking as confined to what humans do through language and its intentionalities. I suggest that Ihde's approach to voice and listening resonates with what is broadly figured as new materialism ${ }^{2}$ as well as with recent work by Erin Manning with the valuable concept of more-than-human: 'For me, the more-than-human is a way of making operative ways of thinking the nonhuman without excising the force of human complicity from these worldlings' (Manning, 2016, pp. 233-234).

Across new materialism and related approaches it becomes more possible to engage in Ihde's listening to voices with and beyond the human - the literal voices of things and of nature - as they speak and as they remember. As Karen Barad puts it, for feminists like Vicki Kirby and herself, matter speaks: 'Matter feels, converses, suffers, desires, yearns and remembers' (Dolphijn and van der Tuin, 2012, p. 59; emphasis added; see also p. 108). Rick Dolphijn and Iris van der Tuin (re-reading Vicki Kirby) also understood that 'matter appears as something that is not only spoken about or spoken with, but rather as itself something simply speaking' (2012, p. 108; emphasis in original). This approach to speaking and listening runs across the varieties of approaches within new materialism (and posthumanism). For new materialist thinkers such as political philosopher Jane Bennett, this listening is a way of attending to a thing - not to its experience from its point of view, which as humans we cannot penetrate, although we can sense it (hence, by the way, her acceptance of an inevitable anthropomorphism) - but to its vibrancy.

While (new) materialism's ethical and relational ways of listening to voices and memory seem more or less recent (especially if we fail to remember the West's own 'pre-scientific' and animist past), there are of course cultures which have listened to these voices in sophisticated ways for a very long time, beginning with First Nation peoples. Where I am located, it is Indigenous Australians who remind us of the materiality of voice, the multiplicity of voice and the groundedness of voice in country: country that knows, country that feels and country that speaks. Indigenous understandings also suggest, in my view, that a strict binary division between 
literal and metaphorical is too limiting for a new materialist apprehension of voice, speaking and listening.

Anthropologist Tim Ingold, also deeply influenced by the time he spent with Indigenous people, alerted readers of his Being Alive to the way the world is 'telling us things' (Ingold, 2011, p. xii) - a telling (which to me is a voiced telling) that reverberates with the vibrancy that is part of being alive, of being in the world. In this sense, the event of voicing speaks not just the speakers and their materiality but also the assemblage of which they (and the listener) are a part. With new materialism, we can apprehend speaking as of and from an assemblage. Philosopher of science Vinciane Despret draws out the forceful aspects of assemblages or, in the original French she prefers, agencements - 'an active process of attunement that is never fixed once and for all. An agencement is a rapport of forces that makes some beings capable of making other beings capable, in a plurivocal manner' (Despret, 2013, p. 38). Voice speaks forcefully in Despret's figuring, with its plurivocal manner and its attunement. And the forces that attune agencement and its agencies, Despret continues, do not just induce, arouse, spark, instigate, engage and inspire; they evoke and provoke others to do things (Despret, 2013, pp. 38, 40). In short, they speak performatively. Figuring both forceful action and the state it produces and is produced through, Despret's agencement brings together what are translated as agency and assemblage; indeed, it understands the way they are always/already together, producing each other. While I agree with her arguments, for convenience I will continue to use the more familiar term assemblage, now, however, inflected by this complexity that Despret points out. ${ }^{3}$

When an assemblage speaks, it voices its forces, its changing relationships, its potentials, rather than some unchanging, fixed essence. Let us take, for example, the voice of the sea, which has spoken very differently over time and place, according to cultural historian Alain Corbin's The Lure of the Sea. (While some may read Corbin's sea as speaking metaphorically, I propose that through new materialist listening we can hear a blurring of the metaphor and literal divide in his voices of the sea). When Corbin explored changing perceptions, desires, emotions, experiences of the sea, he listened to its very different voices in the past in the West. He argued that before the mid- $18^{\text {th }}$ century the sea was repulsive and spoke, I would note, in a very different voice - roaring with anger, moaning with premonition:

With few exceptions, the classical period knew nothing of the attraction of seaside beaches, the emotion of a bather plunging into the waves, or the pleasures of a stay at the seaside. A veil of repulsive images prevented the seaside from exercising its appeal [...] In any case the ocean spoke to pious souls. Its roaring, its moaning, its sudden bursts of anger were perceived as so many reminders of the sins of the first humans, doomed to be engulfed by the waves; its sound alone was a permanent appeal to repent and an incitement to follow the straight and narrow path [...]. (Corbin, 1995, pp. 1-3; emphasis added) 
Repulsive images, repulsive voices. The 'cries' and 'howls' of the sea and its monsters would recede - even though they would still return at times, attenuated, to haunt imaginations - ceding way to different voices (Corbin, 1995, chapter 1). Around the mid- $18^{\text {th }}$ century the sea would voice new emotions and provoke different perceptions and affects, as it was inflected through and listened to within different assemblages - shaped by travel and travel writing, landscape painting, Romanticism and the Sublime, bathing machines, medicine and natural science. In short, what we can listen to in Corbin's history is that, within different assemblages, people listened to the sea differently as it spoke to them differently.

A final word about voice and new materialism. While certainly voice does sound, and while it may be musical in some of the artworks I discuss here, there is something about voice that new materialism helps us apprehend (and vice versa). With a vibrancy, to which new materialism is attuned, voice calls out, calling upon others to listen, to think. This is not a call constructed by the listener, human or otherwise - even as they listen within an assemblage - but a call from, a call upon, a call to - a call that affects and effects. It is a call of life. This is why I propose to apprehend it as voice, rather than subsume it within sound or music: it is voice that provokes a foregrounding of relationality and, with it, ethics and politics.

\section{... and memory}

New materialism inflects the way we perceive memory. Through the prism of new materialism, as we listen to voice anew, we can make audible different understandings of memory. We can attune to memory as it ebbs and flows in and out of the folds of time and place, animating and unsettling a sense of place and enlivening and disjoining a sense of time. This memory is not fixed as a dead and gone history; rather, it is forceful and creative. As Karen Barad explains, 'Memory is not a matter of past but recreates the past each time it is invoked' (Barad in: Dolphijn and van der Tuin, 2012, p. 67). And memory - material memory - is a matter of perception. In a layered and complex way, perception is 'already memory', and memory and materiality intertwine to produce 'memory effects' (Schlunke, 2013, pp. 253, 260). To listen to the voicings of these intertwinings of memory and materiality, I turn now to my artful examples.

\section{Audio-books}

Books hold memories deep in their material selves. This is what I perceive when I encounter the work of the Sound Book Project. These artists and musicians make performances with books, through a collaboration with each other and with the books. These are performances which I would like to figure as audio-books. In these performances, the Sound Book Project makes the books their instruments - and to 
my listening, tuned to the something more that an instrument can play - with a life and memories and voices of their own. When the artists making the Sound Book Project provoke and convoke these memories to speak and enable their audiences to listen to them, something unexpected and wonderful emerges.

\section{Interacting with books in a new and surprising way, suddenly the books will trigger sound by the turn of a page. The books speak for themselves. The books will be wound, spring, strummed, slapped and thrown and a soundscape will evolve around the per- formers. The tactile nature of the book creates a sensual response that [...] is emo- tional and aesthetic. Triggering memory and emotion [...] Crack the Spine. Strum the pages. Play the fragments of memories (Sound Book Project, 2016; emphasis added)}

What I notice in this text is the way, within the space of a sentence, the interacting human subjects suddenly merge into the books as themselves speaking subjects. Or perhaps they were always entangled in their subjectivity and voices? And so it emerges in the work itself - as they wrote, so they performed. In their performances the books both spoke for themselves and in interaction with the artists and musicians - 'triggering memory and emotion' as they 'crack the spine, strum the pages, play the fragments of memory'.

The Sound Book Project is a project that delights and disrupts books, sound, voices and reading. Lured in by their promise that the 'books speak for themselves', I listened online to the video which documented their live performances. The promotional video opens with hands turning pages, conveying a voice of the pages in action. I perceive this as the first voice of the book, and it is a voice so familiar that we do not often notice it as it speaks of the sensual engagement of hand and paper - gesture and thinking - that is the reading of a physical book. This gesture calls on the pages to speak their materiality and the memories they hold. Memories of other readers' hands caressing them. Memories I feel in my own hands. For me, this gesture, like the gestures throughout the performance, works as what Erin Manning figures as a minor gesture, 'invent[ing] its own pulse' and 'activat[ing] new modes of perception' and 'punctually reorient[ing] experience' (Manning, 2016, pp. 1-2). In this minor voice they speak the memory of holding books and that books hold, not in some major way as dead nostalgia for the pre-digital, but as a reminder of the something else and something more that is the assemblage of a book. ${ }^{4}$

As the performance continues and things get more lively - be warned, this could be distressing to some bibliophiles - there is ripping and scrunching hands/pages voicing books' endangered status in our digital world. Again, predictable nostalgia and its reverences are eschewed in these ripping and scrunching gestures, whose rhythms enter my own body as it attunes to those of the performers. Things then calm down, for a minute, as the intimate, gestural and tactile quality of reading books is spoken by tapping and thumping voices, as hands tap covers and covers speak back. And then things hot up again with more cover versions, the voice of 
covers thumping their innards and thumping other books. Banging, thumping, thrumping voices then cede to strumming voices of rubber bands holding books together. I am enlivened as they call to me to sense the musicality of their inner or, should I say, outer life. As the performance unfolds and the assemblage grows, voice, memory, sound, music entangle in enchanted and surprising ways.

The gestures that speak in the works of the Sound Book Project take us beyond the familiar, calling from and on the books to voice their physical selves - selves which bring tactile pleasure, which we remember, again, each time we encounter a book. The assemblage of hands, pages, books, rubber bands that make this particular performance becomes denser when a typewriter speaks up, telling us of the keys remembered in the letters in the words in the books in the artists' hands. Bells of all sorts, including typewriters signalling the end of the line, punctuate the assemblage's sentences. I am rhythmically called into the assemblage as a listener, as one who remembers all the tactile and sensual pleasure of reading books.

As the performance continues, I listen to human voices, joining the more-thanhuman, speaking the pages' words. Somehow, though, in this gesture, a humanist quality of these voices is attenuated as they are enmeshed in this very vocal assemblage. Are they speaking the written words, or are the written words speaking themselves with these human voices - a sort of ventriloquism, as Steven Connor (2000) might have it? Attuned to the words and the pages and the books and their covers and each other, the human voices in the Sound Book Project also evoke memories of the times when people read aloud to themselves and each other. And cutting into those memories from a different direction, eschewing nostalgia or even the fixity of history, the books in this project - and the human voices that speak them - speak each other and speak back.

\section{Performance lectures}

Performance lectures are an art form that hinges between performance and document. They perform the voices of memory held in the documentation and archives with which they engage. Evoking the memory of documenting and archiving, performance lectures engage with questions of documentary and archiving, writing and performance, and voice itself. They are moved not by some fixed historical understanding of memory, but by affect - not just in the documented work they play with, but also in their own performance of documenting. To the question posed by the 2016 performance lectures at Melbourne's MPavilion, 'What is at play when we give voice to an image?' I would add, what is at play when we attune to the voice that is speaking in the image that is a document?

In her presentation at this event, artist Gabrielle de Vietri helped me to understand voicing performance lectures as a way of documenting and dealing with 
documents. De Vietri began her performance by speaking memory, memory of the place in which she was speaking - the Aboriginal land that was occupied by white settler colonists. She remembered the specific history of the place where she was standing. That place is now the site of Melbourne's MPavilion, an ephemeral architectural event of a 'building', which changes its form, but not location, each year. In the Australian summer of 2015/6 it is an open structure protected by a series of 'umbrellas'. 'When I stand under an umbrella do I understand the umbrella?' asks de Vietri, opening her exploration of understanding and place and, for me, memory.

How do I understand the memory that was voiced in this performance lecture? So many of the voices that made up the assemblage seemed so here and now - the birds, the nearby traffic, the wind - calling out the situated-ness of the event. As did the human voices entangled with them in the assemblage - the shuffling, coughing, laughing and sniffling audience that spoke to the artist of our presence, our listening bodies, while the artist's own breath and tongue and mouth spoke to us of her bodily, situated understanding. And there was the mediating voice of the microphone, which asserted its sometimes amplifying, sometimes distorting, sometimes interruptive part to play. Yet even in this very present assemblage memory was not just spoken about, but spoke. Let me return to the gesture of reading aloud (which de Vietri performed and spoke about) with one of her examples. Among the media documents that she engaged with was a clip from the vast archives of Hollywood films, a clip in which a letter spoke. In this scene the noisily unfolding letter spoke above the sound of tell-tale music, insistently voicing its materiality, and then the ventriloquial voice of a narrator spoke the sender's words on the page. Unfolding and holding in his hands the letter (which spoke of conversations past and having the last word), our troubled hero, Tom Cruise, then sniffled and breathed his response. The small scene spoke in reminder of how memory is shaped by media, through the memories of which we experience places, gestures and events in our own lives.

Performance lectures also bring up questions about documentation itself and how its memory is an active (verb of) remembering. Performance theorist Philip Auslander pointed importantly to the performativity of documentation itself, where 'the act of documenting an event as a performance is what constitutes it as such' (Auslander, 2006, p. 5). The documenting document becomes something other, something more - not 'an indexical access point to a past event but [...] itself [works] as a performance that directly reflects an artist's aesthetic project or sensibility and for which we are the present audience' (Auslander, 2006, p. 9). In short, we can understand the memory of documenting and archiving as not fixed or 'indexical', but as active and performative. In a way the voices of documentation are haunted by the memory of the performance, and the elusive performance is haunted by the documentation which will 'follow' it. 
Monica Ross worked with the concept of the untimely to understand the way performance and its documentation trouble our sense of both time and of the 'original'. And, I would add, our sense of memory itself. Ross argued that performance is in fact always already untimely because of its uncanniness, ephemerality and premonition of absence (Ross, 2007a, 2007b, 2007c). This concept of untimely resonates with voice, which is also haunted by ephemerality and 'premonition of absence'. Ross argued that paradoxically you are invited 'to be at once in the present and elsewhere' with documentation of performance (Ross, 2007a, pp. 106-107). I sense here memory speaking both forwards and backwards at the same time, or untime. As archiving artist Jane Birkin put it about her practice, 'In common with archival objects and descriptions, the objects and descriptions that I capture, perform, and interrogate are situations that are discrete and unaffected by outside time, but they are rendered time-critical and timeless through processes of documentation, preservation and storage; they are all at once temporal, atemporal, and supertemporal in nature' (2015). They are, thus, inflected by the memory they voice.

\section{Remix}

Jane Birkin's paper, which was written for the journal issue 'Archives Remixed', reminds me of remix - and the ways that remix practices sample archives to become a speaking memory. In a sense, remix practice is about memory, a collaborative memory between what is remixed and the remix work it becomes. It is a way we remember media through media. And nowhere more palpably than in the stunning remix works of sampling artists Dan and Dominique Angeloro, known collectively as Soda_Jerk. ${ }^{5}$ Their work exemplifies what I have elsewhere called unvoice, where voice track and image track in media and artworks are disjointed and out of sync in ways that disturb both and their usual relationship. ${ }^{6}$ Soda_Jerk's sampling remixes play with this unvoice in ways that are both untimely and uncanny, hauntingly disturbing a sense of memory time's 'normal' flow from present to future - what Manning calls the 'deja felt', the memory of the future (Manning, 2016, pp. 50-51) haunts the present.

This is particularly exemplified in their hauntological series Dark Matter (20052012), a 'séance fiction where encounters are staged between the past and future selves of a deceased screen star' (Soda_Jerk, n.d.). One of the works in the series, The Time that Remains (2012), is, they tell us, a

gothic melodrama [in which] Joan Crawford and Bette Davis perpetually wake to find themselves haunted by their own apparitions and terrorized by markers of time. Isolated in their own screen space, each woman struggles to reclaim time from the gendered discourses of aging that conflates older women with a sense of expiration and invisibility. (Soda_Jerk, n.d.) 
In the looping repetitions of the installation of The Time that Remains, two channels of video speak to each other and to the audience in untimely and uncanny voices. On one screen one actress sleeps and the other wakes, and then vice versa as the first screen gives unto the other. It is as if each actress is experiencing both a waking and dreaming nightmare - as if they are not just experiencing their own nightmare but also each other's. The almost seamless assemblage of samples on each channel calls to the sleeping actress in the other to respond, to awaken. On one screen Joan Crawford wakes to be confronted by her older self 20 years later. And so are we. We cannot ignore the urgent call of time's passing as it is voiced by ticking clocks, nor can we escape the evanescence of life's spark as it is voiced by lighting matches and burning twigs in a log fire. And the inevitability of aging into invisibility (and inaudibility) calls to both the actresses and the audience - in fleeting footsteps.

Through stunning editing in The Time that Remains time moves back and forth almost seamlessly (the almost seamlessly of unvoicing), and one scene speaks its memories of and to another. And so the dripping rain and shattering glass that voice inevitable and melancholic disintegration in one scene cut into pouring water and clinking ice and shattering glass in another. Crashing waves, too, demand that we heed their voicing of the inevitability of time rolling and roiling on. As the older Crawford faces her younger self, time's passing etches the grain of the Hollywood voices: as she speaks wistfully of the time that has passed, the grain of her voice tells the same story. Crawford's gesture of grabbing the hands of a clock hoping to still the voice of time passing is futile, as the inevitably dripping rain asserts.

If the human voice is brooding in the assemblage in which the younger Crawford faces the older Crawford, it is appropriately stormier for the confrontation between Bette Davis' younger and older selves. The cuts and samples on this screen remember the horror that became Bette Davis. While visually shadows play across scenes throughout, they are made all the more palpable by the reverb on the voice singing - 'As time goes by'. (Was this in the original films or did they add it? I cannot remember.) As the younger Davis shape-shifts visibly into the older, she gasps, as if in call, and response, both to what she sees and to what she/we remember of Crawford's dry sobs over the same terror. Once more clocks speak, as if across time and across screens, voicing time's ineluctable passage; and thunder and wind and frantic footsteps voice the stormy inevitability of aging for Hollywood actresses - and, through them, call out to all women who watch and wait. Rolling waves tell us, over and over again, that time rolls on, inevitably - leaving only time remaining. And so, what remains in my memory of The Time that Remains is memory and time. 


\section{Memory, time and place}

Memory and time, memory and place speak at the Edge of the Trees (1995), an installation, which speaks memories of its site at the Museum of Sydney (built on the site of the first Government House in Australia). Janet Laurence made this affective work in collaboration with Indigenous artist Fiona Foley, to whom she turned for the Eora memory of that place. The work co-composes a collaboration between the artists, the site, materials and all of their memories. Standing tall in the assemblage, which is this work, is a 'forest' of 29 massive pillars. As you walk amongst them, you listen to the reverberating names of 29 Aboriginal places from around Sydney, voiced by Aboriginal voices. They speak in resonance with, enliven and reframe botanical and historical names, burnt and carved in Latin and Aboriginal languages, along with the signatures of First Fleeters who confronted the first inhabitants of the place. ${ }^{7}$ In a way Edge of the Trees restages that meeting, voicing a conversation between these two experiences and their memories of the 'same' event.

Memory is material and material memory matters at this edge of the trees. The work is created from materials that have changed from living form in the ground to a living form of memory on the ground, as Laurence puts it. She talks about the work as a 'mapping of the memory of the site', explaining, 'I became really interested in the idea of the memory of the site, that is the botanical memory, the Eora memory, and the colonial memory' (Mordaunt, 2015). It is these material memories, as she puts it, that are voiced in the assemblage that is the work.

When I recently revisited the work, to listen again, I found that sadly the recorded voices were not working. I decided to listen through memory and documentation. ${ }^{8}$ Looking at Internet images of audiences I remembered in my own body the gesture of leaning in to listen - evoking the sense that these voices have been muted and require an effort, a desire to listen to them. And when I did listen to the recordings again, through documentation, I remembered how haunting and moving they were, dense with memory and affect. Their layerings evoked the layers of history of that specific place and the repetitions provoked memories of the repetition of what has been done to Indigenous Australians, not just once, but again and again. There was an intimacy to these voices of memory, calling me to lean closer to listen. There was a fragility typical of Laurence's work, but also a persistence and an assertion of life. As one voice repeated the name of the place that another voice named, I felt the pull of call and response. I attuned to the call and response at the edge of the trees that spoke the memories of a place where 'two cultures looked through to each other - here they mingle and intertwine a weaving towards the future' (Laurence, n.d.). This is a weaving that calls to us from the materially of memory. 


\section{Conclusion}

In this essay I have listened to various voicings of memory. I have attended to the voices, speaking of and from assemblages, remembering my own situated listening part to play within them. Attuned by new materialism, I have perceived these memory voices as affective and performative, evoking and provoking my responses to their calls. As part of the assemblages that are these works, I have listened to their, and my, memory as it is voiced across time and place. And in response they have told me of the forceful materiality of remembering and of memory.

\section{Acknowledgements}

I pay my respects and acknowledgments to all Traditional Custodians on whose land I live, work and travel through.

I develop the ideas about voice and new materialism further in: Neumark, Norie. (2017). Voicetracks: attuning to voice in media and the arts. Cambridge, MA: MIT Press.

\section{References}

Auslander, Philip. (2006). The Performativity of Performance Documentation. PAJ 84: A Journal of Performance and Art.

Bandt, Ros. (2001). Sound Sculpture. Sydney: Craftsman House.

Birkin, Jane. (2015). Art, Work, and Archives: performativity and the Techniques of Production. Archive Journal, 5(fall). Archives Remixed. http://www.archivejournal.net/

Cavarero, Adriana. (2005). For More Than One Voice: Toward a Philosophy of Vocal Expresssion. Translated by Paul A. Kottman. Stanford, CA: Stanford University Press.

Connolly, William. (2013). The 'New Materialism' and the Fragility of Things. Millennium: Journal of International Studies, 41(3).

Connor, Steven. (2000). Dumbstruck: A Cultural History of Ventriloquism. Oxford: Oxford University Press.

Corbin, Alain. (1995). The Lure of the Sea: the discovery of the seaside 1750-1840. Translated by Jocelyn Phelps. London: Penguin Books.

Cull ó Maoilearca, Laura. (2012, 2015[PB]). Theatres of Immanence: Deleuze and the Ethics of Performance. Houndmills, Basingstoke and New York: Palgrave Macmillan.

Despret, Vinciane. (2013). From Secret Agents to Interagency. History and Theory, 52(4).

Dolphijn, Rick \& van der Tuin, Iris. (2012). New Materialism: Interviews and Cartographies. Ann Arbor, MI: MPublishing and Open Humanities Press. http://www.openhumanitiespress.org/books/ titles/new-materialism/.

Haraway, Donna. (1988). Situated Knowledges: The Science Question Questions in Feminism and The Privilege of Partial Perspective. Feminist Studies, 14(3): 575-599.

Ihde, Don. (2007). Listening and Voice: Phenomenologies of Sound. $2^{\text {nd }}$ ed. Albany, NY: State University of New York Press.

Ingold, Tim. (2011). Being Alive: Essays on Movement, Knowledge, and Description. London and New York: Routledge. 
LaBelle, Brandon. (2014). Lexicon of the Mouth: Poetics and Politics of Voice and the Oral Imaginary. New York: Bloomsbury.

Laurence, Janet. (N.d.). http://www.janetlaurence.com/edge-of-the-trees/

Manning, Erin. (2016). The Minor Gesture. Durham, NC: Duke University Press.

Mordaunt, Richard. (2015). Janet Laurence - The life world. https://www.youtube.com/watch?v=tHxXxaTv6tw

MPavillion. (N.d.). Interval performance lecture series, 'Between a thought and a feeling'. https:// www.youtube.com/watch?v=gcxqglIRPoA

Neumark, Norie. (2017). Voicetracks: attuning to voice in media and the arts. Cambridge, MA: MIT Press.

Neumark, Norie, Gibson, Ross \& van Leeuwen, Theo. (Eds.). (2010). Voice: Vocal Aesthetics in Digital Arts and Media. Cambridge MA: MIT Press.

Next Wave. (2016). Interval Performance Lecture Series: 'Between a thought and a feeling'. http:// nextwave.org.au/event/interval-performance-lecture-series-between-and-thought-and-afeeling/

Ross, Monica. (2007a). The Trouble with Performance Art. In: This Will Not Happen Without You: From the collective archive of The Basement Group, Projects UK and Locus+ (1977-2077). Newcastle upon Tyne: Locus+Publications.

Ross, Monica. (2007b). Empyre. 20 November 2007. https://lists.cofa.unsw.edu.au/pipermail/empyre/2007-November/000135.html.

Ross, Monica. (2007c). Empyre. 25 November 2007. https://lists.cofa.unsw.edu.au/pipermail/empyre/2007-November/000153.html.

Schlunke, Katrina. (2013). Memory and materiality. Memory Studies, 6(3).

Soda_Jerk. (N.d.). http://www.sodajerk.com.au/video_work.php?v=20120921063658

Sound Book Project. (2016). http://www.soundbookproject.com/

Sydney Living Museums. (N.d.). Edge of the Trees. http://sydneylivingmuseums.com.au/exhibitions/edge-trees

Thomaidis, Konstantinos \& Macpherson, Ben. (2015). Voice Studies: Critical approaches to process, performance and experience. London and New York: Routledge.

Voegelin, Salomé. (2010). Listening to Noise and Silence: Towards a Philosophy of Sound Art. New York: Continuum.

Voegelin, Salomé. (2015). [Thinking Resonance 01] Listening to Inner Voices and Sonic Possible Worlds: An Interview with Salomé Voegelin. Sonic Field. http://sonicfield.org/2015/12/listeningto-inner-voices-and-sonic-possible-worlds-an-interview-with-salome-voegelin/

\section{Notes}

1 See, for example, Neumark et al. (2010), Cavarero (2005), Connor (2000) and LaBelle (2014).

2 As I discuss elsewhere (Neumark, 2017), but cannot detail here, I deploy new materialism as an umbrella term - operating like a Foucauldian toolbox of concepts - unfolding across philosophy, biology and the humanities, opening up (from) fundamental critiques of anthropocentrism and human subjectivity to move beyond anthropocentric thinking, aesthetics, ethics and politics (see, e.g., Connolly, 2013). And while there are of course important differences between theorists I refer to here who fall under this umbrella - as well as others who gather under the posthumanism umbrella - it is noteworthy that they share a sense that matter speaks and remembers.

3 Again, it is not possible to detail here the various different approaches to assemblage. I would note, in relation to Despret, whose approach I work with, that Erin Manning makes a similar point, also preferring agencement as the 'concept best capable of carrying agency [...] a sense of a mobilizing [...] It is emergent and co-compositional' (Manning, 2016, p. 134). 
4 Manning cites Deleuze and Guattari on the agencement, the assemblage, that is a book: 'There is no difference between what a book talks about and how it is made'. It is 'an assemblage [agencement] in connection with other assemblages [agencements]' (Deleuze and Guattari in: Manning, 2016, p. 124).

5 Their delightful autobiographical remix can be found at: (https://www.youtube.com/ watch?v=XvsixXqC-gM)]

6 See Neumark (2017).

7 The sculpture's name comes from historian Rhys Jones' essay: 'the "discoverers" struggling through the surf were met on the beaches by other people looking at them from the edge of the trees. Thus the same landscape perceived by the newcomers as alien, hostile, or having no coherent form, was to the Indigenous people their home, a familiar place, the inspiration of dreams' (Sydney Living Museums, n.d.).

8 I relied on the cd in Ros Bandt's Sound Sculpture (2001) as well as various online documents, including a documentary by Richard Mordaunt (2015). I do have one small quibble about the latter, despite its sensitivity. I was annoyed by the way Mordaunt (like so many documentary makers) added 'haunting' emotional music on top of sound from the installation. To me, the work was already hauntingly affective on its own, through the voices themselves. 